\title{
Insulin Therapy in Type-II Diabetes Mellitus - Is it Feasible and Acceptable?
}

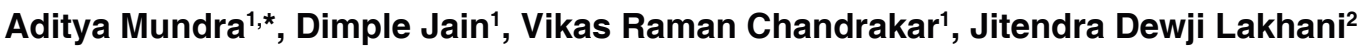 \\ ${ }^{1}$ Department of Pharmacy, Sumandeep Vidyapeeth Deemed University, Vadodara, Gujarat, INDIA. \\ ${ }^{2}$ Smt. B.K. Shah (SBKS) Medical Institute and Research Center, Sumandeep Vidyapeeth (Deemed University), Vadodara, Gujarat, \\ INDIA.
}

\begin{abstract}
Background: Insulin, being the mainstay of treatment for type 1 and certain situations in type 2 Diabetes mellitus (DM), is still not properly utilized. Thus, this study was done to know the barriers that lead to suboptimal utilization of insulin therapy by stakeholders particularly in our group of patients who were mostly from rural background. Methods: An observational, cross-sectional study with sample size of 100 patients with Type 2 DM that were prescribed with insulin or were already on insulin was done. Patient were interviewed on basis of pre-structured socio-demographic, knowledge, attitude and practice questionnaire and accordingly counseled. Data was analyzed by percentages and student's $t$-test. Results: Around $58 \%$ patients, in whom insulin was indicated, were taking insulin therapy. Limited knowledge about the disease and insulin, in addition to wrongful attitude and practices were barriers to therapy. Less than $50 \%$ patients had proper knowledge and understanding about insulin therapy. They had misconception of "habit" forming character of insulin and of hypoglycemia. Social stigma, inconvenience, life-long therapy commitment, cost, phobias were other causes for resistance to the use of insulin. Conclusion: This study concludes that by understanding patient's attitude towards insulin therapy healthcare professionals can aim to modify their misconceptions. Difference can be made by educating patients through proper counseling by clinical pharmacist in harmony with other healthcare professionals. This will not only help in delivering proper patient-centered care but will also help in improving the way patient looks at diabetes and insulin, thus revolutionizing the diabetic world.
\end{abstract}

Key words: Clinical Pharmacist, Type2DM, Insulin Therapy, KAP Survey, KAP Questionnaire.

\section{INTRODUCTION}

Diabetes mellitus, characterized by chronic hyperglycemia and impaired carbohydrate, lipid and proteins metabolism was long considered a disease of minor significance to world health, but is now taking its place as one of the main threats to human health in the $21^{\text {st }}$ century. ${ }^{1-3}$ It currently affects over 366 million people worldwide and this figure is likely to double by 2030. It has emerged as a major public health problem with India ranking second having 65.1 million diabetic people.

With the introduction of insulin in 1921 by Banting and Best the dreadful picture of diabetes was about to change but due to some of the misconceptions and beliefs of the population the revolution that insulin could have bought in the treatment of diabetes just remained a dream of many.
Insulin is safe and effective; It produces a remarkable life expectancy for diabetics and can improve or correct many of the metabolic abnormalities. With a huge base of diabetic patients in India, it is anticipated that only $25 \%$ of this population is receiving treatment. Thus, it is important to know the awareness level of a disease state and its management (Here, in the light of insulin therapy) in the population so as to figure out the reasons for this level of setback to insulin therapy, which will help in providing better healthcare and reduce related morbidities. ${ }^{4,5}$

A good deal of work has been done in this area, but our investigation is unique in providing an insight into the economically weaker sections of the society to know whether insulin therapy is feasible and acceptable?.
DOI: 10.5530/ijopp.12.2.19

Address for correspondence: Aditya Mundra, Department of Pharmacy, Sumandeep Vidyapeeth (Deemed University), Piparia, Waghodiya, Vadodara, Gujarat-391760, INDIA.

Phone no: +91 7987689281 Email Id: aditya94mundra@ gmail.com

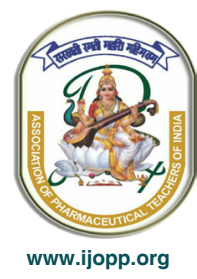




\section{MATERIALS AND METHODS}

\section{Study design}

A prospective cross-sectional study was conducted at Dhiraj General Hospital, Pipariya, Vadodara. The study was initiated after the approval of the institutional ethics committee with a sample size of 100 .

\section{Inclusion criteria}

All the patients of age 18-60 years with uncontrolled Type 2 Diabetes Mellitus already on insulin therapy or those in whom insulin was indicated and were reluctant to take insulin therapy were taken for the study.

\section{Exclusion criteria}

Pregnant women and mentally incompetent patients.

\section{Study material}

Forms: Informed consent form (ICF), Patient information sheet, Patient Medication record sheet.

Questionnaires: Modified Socio-demographic Questionnaire, Modified Knowledge, Attitude and practice Questionnaire.

\section{Methodology}

- Keeping in mind the tool used by Choudhury SD et al. ${ }^{6}$ and according to the results of our pilot study that we conducted in about 50 patients ( 25 on insulin therapy and 25 not on insulin therapy) we framed our socio-demographic questionnaire, knowledge attitude and practice questionnaire.

- Patient enrollment was started on the basis of inclusion and exclusion criteria.

- Once patient was found to be suitable for the study. Their voluntarily consent was taken by PI.

- Data was obtained and student's $t$-test was used as statistical tool for analysis.

\section{Research and Ethical Committee Approval}

Institutional research and ethical committee approved the study and issued a letter of permission to conduct the study.

\section{RESULTS}

\section{Socio-demographic details}

Table 1 shows patients of different age groups and almost equal number of male and female patients. Almost 31\% patients had secondary education around $36 \%$ of the sample had less than Rs. 10, 000 as their monthly income with $83 \%$ having long standing history of diabetes (Diagnosed $>1.5$ year back).

As shown in Pie-chart (Figure 1), 23\% of patients were not knowing as to why they have been prescribed with insulin therapy, while the rest came out with different answers.

\section{Table 1: Socio-Demographic Data ( $n=100)$.}

$\begin{array}{ccc} & \begin{array}{c}\text { Number } \\ \text { (Male+ } \\ \text { Female) }\end{array} & \% \\ \text { Below 30 } & 5(3+2) & 5 \% \\ 31-40 & 9(8+1) & 9 \% \\ 41-50 & 17(9+8) & 17 \% \\ 51-60 & 38(22+16) & 38 \% \\ 61-70 & 21(11+10) & 21 \% \\ \text { above } 70 & 10(6+4) & 10 \%\end{array}$

2. Gender

\section{Age}

\section{Education}

$\begin{array}{ccc}\text { Male } & 59 & 59 \% \\ \text { Female } & 41 & 41 \%\end{array}$

$\begin{array}{ccc}\text { Illiterate } & 11 & 11 \% \\ \begin{array}{c}\text { Less than secondary } \\ \left(10^{\text {th }}\right) \text { education }\end{array} & 31 & 31 \% \\ \begin{array}{c}\text { Higher secondary } \\ \left(12^{\text {th }}\right) \text { education }\end{array} & 38 & 38 \% \\ \text { Graduate and above } & 20 & 20 \%\end{array}$

4. Income

$\begin{array}{ccc}<10000 & 36 & 36 \% \\ 10000-25000 & 32 & 32 \% \\ 25000-50000 & 23 & 23 \% \\ 50000-10000 & 7 & 7 \% \\ >100000 & 2 & 2 \%\end{array}$

5. Family

history

$\begin{array}{ccc}\text { Yes } & 53 & 53 \% \\ \text { No } & 39 & 39 \% \\ \text { Not sure } & 8 & 8 \%\end{array}$

6. Diagnosed

$\begin{array}{ccc}<1 \mathrm{y} & 17 & 17 \% \\ 1.5-5 \mathrm{y} & 28 & 28 \% \\ >5 \mathrm{y} & 55 & 55 \%\end{array}$

7. Insulin

Therapy

\begin{tabular}{ccc} 
I did not start. & 42 & $42 \%$ \\
$\begin{array}{c}\text { Immediately after } \\
\text { diagnosis. }\end{array}$ & 17 & $17 \%$ \\
$\begin{array}{c}\text { Some years after } \\
\text { diagnosis. }\end{array}$ & 41 & $41 \%$ \\
\hline
\end{tabular}

Indian Journal of Pharmacy Practice, Vol 12, Issue 2, Apr-Jun, 2019 


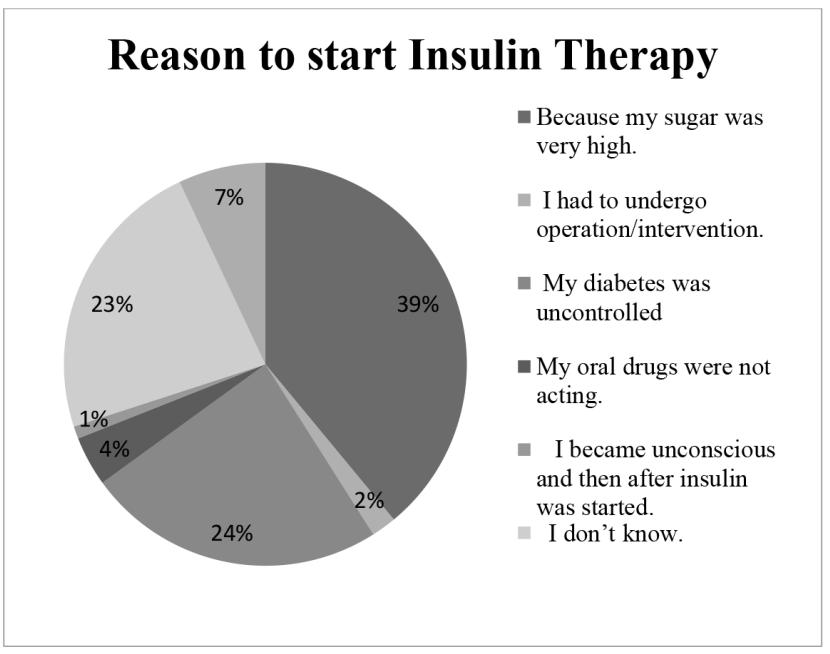

Figure 1: Reasons to Start Insulin Therapy.

As far as issue on "Initiation of insulin therapy" is concerned, $27 \%$ of the study patients did not start insulin therapy at all even after being advised and 56\% sample that started a little late than were advised.

\section{Knowledge}

Table 2 and Figure 2 suggests that the knowledge of the patient regarding insulin as a therapy and diabetes as a disease is not apt. About $41 \%$ of sample population thought that there is a relation of diabetes with insulin therapy but conversely 59\% were unable to comment on the same.

Regarding the knowledge of "Type and Brand" of insulin, a proportional number of people that is $84 \%$ were unaware about the type of insulin given to them. Also, $6 \%$ and $46 \%$ of the patients were aware of premix insulin and plain insulin to be adjusted with their meal pattern and plan. About $68 \%$ of the study population patient thought that insulin when started becomes a lifelong therapy. About $60 \%$ of the sample was aware of the complications related to diabetes conversely $63 \%$ of the same sample felt that such complications cannot be better dealt with insulin therapy.

Majority knew regarding site for insulin injection and about $79 \%$ of the total population gave right answers when inquired about the same. There were some bizarre answers also like it can be given on the whole body, chest and lower limb. Around $61 \%$ of the sample population was unaware of hypoglycemia and its symptoms.

Thus, regarding the assessment of knowledge $(t$-value $=1$. 693), we saw many potential and obvious areas where work ought to be done by all the healthcare professionals in harmony to help increase knowledge of the patient

\section{Table 2: Knowledge Assessment.}

KNOWLEDGE

\begin{tabular}{|c|c|c|}
\hline QUESTIONS & $\begin{array}{l}\text { Positive } \\
\text { response }\end{array}$ & $\begin{array}{l}\text { Negative } \\
\text { response }\end{array}$ \\
\hline 1. Insulin is related to diabetes? & 54 & 46 \\
\hline 1B. How? & 41 & 59 \\
\hline $\begin{array}{l}\text { 2. Are you aware about types of } \\
\text { insulin given to you? }\end{array}$ & 9 & 49 \\
\hline $\begin{array}{l}\text { 3. Do you know about premix } \\
\text { insulin? }\end{array}$ & 4 & 54 \\
\hline $\begin{array}{l}\text { 4. Insulin which can be taken } \\
\text { immediately before meal? }\end{array}$ & 24 & 34 \\
\hline $\begin{array}{l}\text { 5. Insulin is needed for daily activity } \\
\text { even if you are not taking food? }\end{array}$ & 15 & 43 \\
\hline $\begin{array}{l}\text { 6. Insulin can be stopped once blood } \\
\text { sugar levels normalize? }\end{array}$ & 32 & 68 \\
\hline $\begin{array}{l}\text { 7. Aware of the complications of } \\
\text { diabetes? }\end{array}$ & 60 & 40 \\
\hline $\begin{array}{l}\text { 7B. Complications can be better } \\
\text { dealt with insulin? }\end{array}$ & 37 & 63 \\
\hline 8. Do you know about insulin pen? & 50 & 8 \\
\hline 9. Aware of $\mathrm{HbA} 1 \mathrm{c}$ ? & 18 & 82 \\
\hline $\begin{array}{l}\text { 10. Where will you be injecting } \\
\text { insulin? }\end{array}$ & 79 & 21 \\
\hline $\begin{array}{l}\text { 11. Reading the package insert } \\
\text { supplied along with insulin? }\end{array}$ & 5 & 53 \\
\hline 12. What is hypoglycemia? & 61 & 39 \\
\hline
\end{tabular}

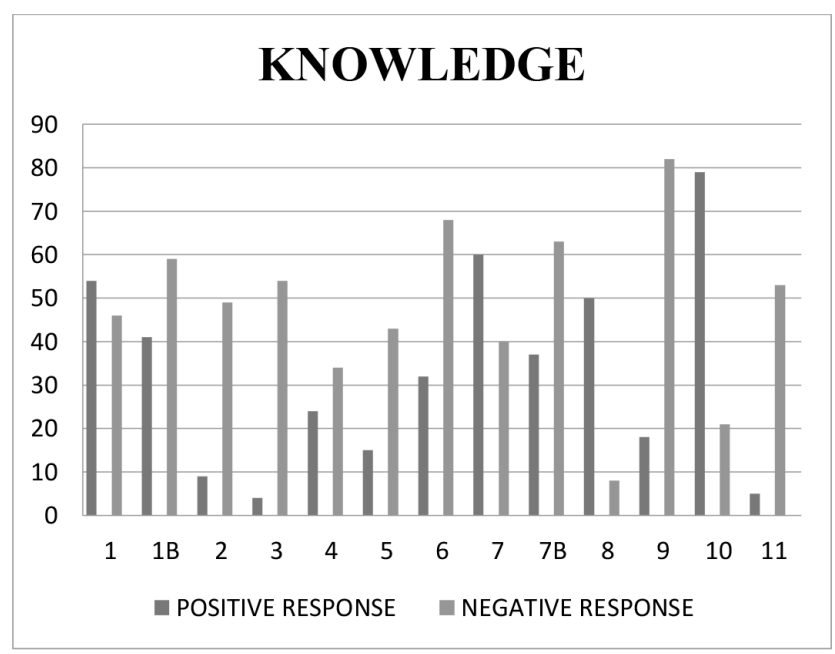

Figure 2: Knowledge Assessments.

regarding insulin therapy and diabetes so as to bring about a better scenario of insulin use and better health perspective to diabetic patient population.

\section{Attitude}

From the data shown, (Table 3 and Figure 3 ) around 13\% of insulin using population thinks that it is habit forming. Also, around $80 \%$ of the sample population thinks that 
insulin is not the ultimate treatment for diabetes.

This study supports previously established factors of "Psychological insulin resistance" to insulin therapy namely "Needle phobia" and "Social stigma" with 79\% and $46 \%$ of the sample reporting the same respectively.

Around 63\% people would like to stop taking insulin therapy if ever they were given a chance to do so; around $42 \%$ of the population samples were unwilling to start insulin therapy. About $49 \%$ of the patient population thought negative about "Insulin", like the therapy may lead to more complications. Detail probing gave us further insight as to why they were reporting like that. It was observed by them that patients who were switched to insulin therapy in chronic kidney disease patients may require hemodialysis which they misconceptualised as complication (Aãdd-Aasar: Gujarati language ever batim) of insulin therapy.

Regarding the cost of insulin therapy, 91\% of patients on insulin therapy found it costly and $96 \%$ people felt it to be cumbersome.

\begin{tabular}{|c|c|c|}
\hline \multicolumn{3}{|l|}{ ATTITUDE } \\
\hline QUESTIONS & $\begin{array}{l}\text { Positive } \\
\text { response }\end{array}$ & $\begin{array}{l}\text { Negative } \\
\text { response }\end{array}$ \\
\hline 1. Insulin is habit forming & 50 & 8 \\
\hline $\begin{array}{l}\text { 2. Insulin is last resort for treatment } \\
\text { of diabetes }\end{array}$ & 20 & 80 \\
\hline 3. Insulin can cause harm & 65 & 35 \\
\hline 4. Are you worried about pricks & 21 & 79 \\
\hline 5. Encouragement by family member & 72 & 28 \\
\hline $\begin{array}{l}\text { 6. Given chance would you stop } \\
\text { insulin }\end{array}$ & 21 & 37 \\
\hline $\begin{array}{l}\text { 7. Insulin has any role in causation of } \\
\text { diabetes }\end{array}$ & 51 & 49 \\
\hline 8. Regarding cost of insulin & 5 & 53 \\
\hline 9. Insulin therapy is cumbersome & 2 & 56 \\
\hline 10. Insulin leads to weight gain & 14 & 44 \\
\hline $\begin{array}{l}\text { 11. Awkward while using insulin in } \\
\text { public }\end{array}$ & 12 & 46 \\
\hline
\end{tabular}

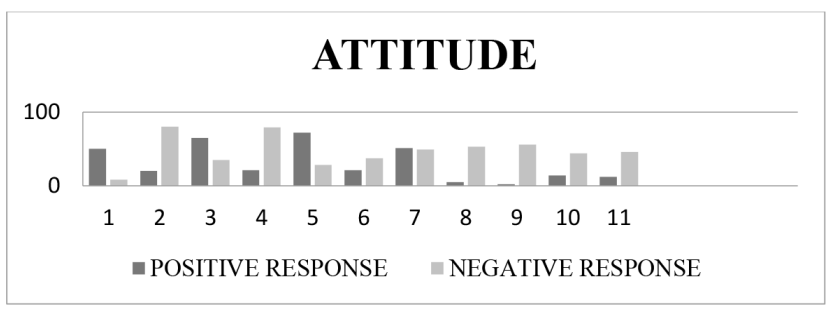

Figure 3: Attitude Assessments.
Thus, assessment of attitude $(t$-value $=1$. 697) delineates many factors that may play a role in changing the mindset of a patient regarding insulin therapy that needs to be looked upon.

\section{Practice}

Around 55\% patient were taking insulin (Table 4 and Figure 4) either by themselves $(n=32)$ or was injected by a family member $(n=21)$, very less number of patient were taking with the help of a doctor $(n=3)$ or would not take at all $(n=1)$. Around $56 \%$ of the sample on insulin therapy told that it was difficult for them to administer insulin.

About $65 \%$ of those taking insulin therapy told that they pinch up the area to be injected with insulin. However around $31 \%$ of those on insulin therapy apply gentle pressure at the injecting site and around 25\% "massage" the site of injection.

With $56 \%$ of the population reporting that it hurts injecting insulin there is almost $50 \%$ of the population knowing that if injected in a proper way it can be pain free. Adding to this a proportion of $30 \%$ of the sample population have reported that injecting insulin is making the site tough. Thus, it is worthwhile to note that how wrongful practices can make a therapy less satisfying and less rewarding.

With around $75 \%$ of the population reporting that they do use different anatomic sites when taking different types of insulin around only $25 \%$ of the population do not reuse syringes for injecting insulin. However, there was only $11 \%$ of the population that got infection at the site of injecting insulin. There were around $81 \%$ of the diabetic sample population that checked their blood glucose levels at home. Around $96 \%$ of the population rotated site of injecting insulin while $57 \%$ of the population do miss their insulin dose.

There were about $87 \%$ of the population that reported having episodes of hypoglycemia of which $32 \%$ required hospitalization for the same but still only $43 \%$ of the population kept simple carbohydrates with them always. Reports of nocturnal hypoglycemia were as high as 64\%.

The results of practice throw light on many aspects of insulin administration and thus patients should be counseled accordingly regarding the dos and don'ts of the insulin therapy for better and satisfying outcomes.

\section{DISCUSSION}

Through this study we wanted to know the barriers to Indian Journal of Pharmacy Practice, Vol 12, Issue 2, Apr-Jun, 2019 
Table 4: Practice Assessment.

PRACTICE

\begin{tabular}{|c|c|c|c|c|}
\hline QUESTIONS & 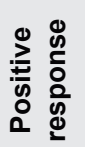 & ஃ & 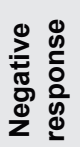 & ஃ \\
\hline $\begin{array}{l}\text { 1. Whom will you like } \\
\text { insulin to be taken by? }\end{array}$ & 32 & 55.17 & 26 & 44.83 \\
\hline $\begin{array}{l}\text { 2. Difficulty in administering } \\
\text { insulin? }\end{array}$ & 25 & 43. 10 & 33 & 56. 90 \\
\hline $\begin{array}{l}\text { 3. Pinch up area to be } \\
\text { injected? }\end{array}$ & 38 & 65.52 & 20 & 34.48 \\
\hline $\begin{array}{l}\text { 4. Do you apply gentle } \\
\text { pressure at the injecting } \\
\text { site? }\end{array}$ & 40 & 68. 97 & 18 & 31.03 \\
\hline $\begin{array}{l}\text { 5. Massaging injection } \\
\text { site? }\end{array}$ & 43 & 74.14 & 15 & 25.86 \\
\hline $\begin{array}{l}\text { 6. Does it hurt injecting } \\
\text { site? }\end{array}$ & 25 & 43. 10 & 33 & 56. 90 \\
\hline $\begin{array}{l}\text { 7. Injecting insulin can be } \\
\text { pain free? }\end{array}$ & 29 & 50.00 & 29 & 50.00 \\
\hline $\begin{array}{l}\text { 8. Injecting insulin making } \\
\text { the site tough? }\end{array}$ & 41 & 70.69 & 17 & 29. 31 \\
\hline $\begin{array}{l}\text { 9. Check insulin before } \\
\text { use? }\end{array}$ & 45 & 77.59 & 13 & 22. 41 \\
\hline $\begin{array}{l}\text { 10. Do you agitate insulin } \\
\text { before use? }\end{array}$ & 29 & 50.00 & 29 & 50.00 \\
\hline $\begin{array}{l}\text { 11. Do you choose different } \\
\text { anatomic site while taking } \\
\text { different insulin? }\end{array}$ & 44 & 75.86 & 14 & 24. 14 \\
\hline $\begin{array}{l}\text { 12. Do you reuse syringes } \\
\text { and needles? }\end{array}$ & 15 & 25.86 & 43 & 74. 14 \\
\hline $\begin{array}{l}\text { 13. Ever noticed infection } \\
\text { at injection site? }\end{array}$ & 52 & 89. 66 & 6 & 10. 34 \\
\hline $\begin{array}{l}\text { 14. Do you check insulin } \\
\text { blood glucose at home? }\end{array}$ & 47 & 81.03 & 11 & 18. 97 \\
\hline $\begin{array}{l}\text { 15. Need to consult the } \\
\text { physician for the same? }\end{array}$ & 39 & 67.24 & 19 & 32. 76 \\
\hline $\begin{array}{l}\text { 16. Need to adjust the } \\
\text { insulin do you take? }\end{array}$ & 27 & 46.55 & 31 & 53. 45 \\
\hline 17. Do you rotate site? & 56 & 96.55 & 2 & 3. 45 \\
\hline $\begin{array}{l}\text { 18. Do you miss insulin } \\
\text { doses? }\end{array}$ & 25 & 43. 10 & 33 & 56. 90 \\
\hline $\begin{array}{l}\text { 19. Ever had hypoglycemic } \\
\text { episode? }\end{array}$ & 8 & 13. 79 & 50 & 86. 21 \\
\hline $\begin{array}{l}\text { 20. Ever been hospitalized } \\
\text { for insulin related } \\
\text { hypoglycemia? }\end{array}$ & 40 & 68. 97 & 18 & 31.03 \\
\hline $\begin{array}{l}\text { 21. Do you carry simple } \\
\text { carbohydrates always? }\end{array}$ & 25 & 43. 10 & 33 & 56. 90 \\
\hline $\begin{array}{l}\text { 22. Ever had nocturnal } \\
\text { hypoglycemia? }\end{array}$ & 21 & 36. 21 & 37 & 63. 79 \\
\hline
\end{tabular}

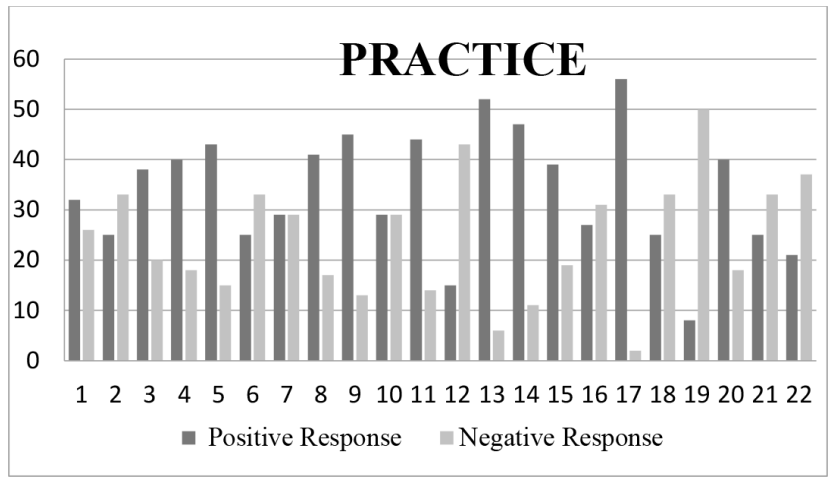

Figure 4: Practice Assessment.

insulin therapy that rural population face, perceive, retort and counteract. Study was conducted at medical college attached Dhiraj hospital which is situated at Piparia village of waghodia Taluka, of Vadodara District. It is a multispecialty hospital having daily 600 patients medical OPD and once a week Diabetic clinic. Many diabetic patients take services from out-patient department, some of which are admitted in the wards and also come to other departments for diabetic complications. They come from the nearby as well as from interiors of Gujarat and Madhya Pradesh. Patients type and mix is different from those coming at primary, secondary as well as corporate multi-specialty hospital. They are from rural background, low to middle income group and of lower educational background. Thus, to know whether it is only their sociodemographic factors or other unidentified factors that are responsible for their reluctance towards insulin therapy, this study was done.

We conducted a pilot study in about 50 patients (25 on insulin therapy and 25 not on insulin therapy) that visited us at medical OPD, Indoor wards or Pharmacycounseling center. In reference with the tool used by Choudhury SD et al. ${ }^{6}$ and also on the basis of results of our pilot study, we framed our socio-demographic, knowledge, attitude and practice questionnaire that were used to interrogate our patients, while Maskari FA et al. ${ }^{7}$ made literate patients to fill out the questionnaires themselves while illiterate participants were interviewed by trained nurses.

As in this study, the same pattern of age distribution was seen in the study done by Jasper et al. ${ }^{8}$ where the participants in this study were between the age group of 51-60 years. Male population was higher than females $(59 \%$ and $41 \%)$ as was the case in the studies conducted by Dinesh et al. ${ }^{9}$ and Choudhury SD et al. ${ }^{6}$ With only $11 \%$ illiterate population our study resonated with the study done by Dinesh et al. ${ }^{9}$ where only $95 \%$ of the participants were illiterate. However, majority were up to primary and secondary education. Again, in our study we had highest 
proportion of population from less than 10,000 monthly family income, while in one study conducted by Shah $\mathrm{VN}$ et al. ${ }^{10}$ the population with annual income less than 20,000 was $39.47 \%$.

In this study the $28 \%$ patients had diagnosis of diabetes of 1.5-5 years duration. In the study of Konduru et al. ${ }^{11}$ duration of disease was $>5$ years in majority whereas $27 \%$ of people were having duration of disease $<1$ year.

Regarding the knowledge about diabetic complications like retinopathy, neuropathy, stroke, Ischemic heart disease and others are concerned, in this study, it was found that around $60 \%$ of the population was aware of the complications related to diabetes. Another fact which emerged from this study was that more than $60 \%$ of the study population felt that such complications cannot be better dealt with insulin therapy.

Moreover, they opined that Insulin may harm the body and may be cause for requirement of hemodialysis. Prevalence of Chronic Kidney Disease (CKD) in adults with type2 DM was $38.3 \%$ in a study of 2006 patients, during 2007-2012 done by WuB et al. ${ }^{12}$ most studies report use of Insulin in severe CKD stages, as insulin is safer in patients having impaired renal function status. Again titration upward can be done by insulin, to achieve proper glycemic control which is associated with a reduction in the onset and progression of diabetic nephropathy. ${ }^{12,13}$ Patients having renal dysfunction may have insulin resistance and may require a higher dose of basal insulin. ${ }^{14,15}$ Insulin therapy thus becomes an important treatment option in patients of diabetic kidney disease. A myth which prevailed in our study patients was that, if insulin is taken, patients may have to undergo hemodialysis in future, while the fact is that it slows the progression of CKD.

During counseling session, a patient should be explained about such confusion related to diabetic complications and complication's natural progression with and without insulin therapy. The difference between FBS, PPBS, RBS and $\mathrm{HbA1C}$ in relation to diabetes control and complications needs a proper understanding and counseling. About $86 \%$ of insulin users had misconception regarding "Habit Forming" nature of Insulin which is also been reported by other Indian studies. ${ }^{6}$ In our study $32 \%$ of the sample feels that insulin can be stopped once blood sugar level normalize which is much higher than what was found in the study done by Choudhury SD et al. ${ }^{6}$ Knowledge of HbA1c reveals the same pattern in both the studies with least as only $18 \%$ population being aware about the same.
Some encouraging results were in relation to sphere of practices related to insulin therapy like majority knew injection technique, about pen device, about rotating site for injection, about Self-Monitoring of Blood Glucose (SMBG). Bad practices were also noted which was in form of not pinching the skin and not injecting it subcutaneously (30\%), giving immediate massage and/ or gentle pressure on the injection site with few others.

It happens that patient needs insulin, doctors prescribed them, but due to attitudinal differences and societal pressure, are reasons for psychological insulin resistance Brod et al. ${ }^{16}$ they may not initiate insulin therapy which was present in $42 \%$ of the population which was reported by Choudhury SD et al. in $12.2 \%$. Thus it is imperative to counsel the patient properly for improvements in their knowledge status regarding the disease for better adherence and good therapeutic outcomes. ${ }^{17}$

\section{ACKNOWLEDGEMENT}

The authors would like to thank their Parents, all the members of Department of Pharmacy and Dhiraj General Hospital, Sumandeep Vidyapeeth University, Vadodara for their constant support and guidance.

\section{CONFLICT OF INTEREST}

The authors declare none.

\section{ABBREVIATIONS}

Type2DM: Type 2 Diabetes Mellitus; KAP: Knowledge,Attitude and Practice; ICF: Informed Consent Form; PI: Principal Investigator; HbA1c: Glycated Haemoglobin; OPD: Out Patient Department.; CKD: Chronic Kidney Disease; FBS: Fasting Blood Sugar; PPBS: Post Prandial Blood Sugar; RBS: Random Blood Sugar; SMBG: Self-Monitoring of Blood Glucose.

\section{SUMMARY}

Limited knowledge, wrongful attitude and practices are having an impact on how insulin is being perceived by the sample population. The reasons for this may be low interest from patient's part or improper counseling from physician due to time constraint. This study highlights the importance of proper and timely patient counseling by clinical pharmacist and other healthcare professionals to obtain better results out of the prescribed insulin therapy.

\section{REFERENCES}

1. Tripathi BK, Srivastava AK. Diabetes mellitus: Complications and therapeutics. Medical Science Monitor. 2006;12(7):RA130-47.

2. Meece J. Dispelling myths and removing barriers about insulin in type 2 diabetes. The Diabetes Educator. 2006;32(1_suppl):9S-18S.

Indian Journal of Pharmacy Practice, Vol 12, Issue 2, Apr-Jun, 2019 
3. National Diabetes Data Group. Classification and diagnosis of diabetes mellitus and other categories of glucose intolerance. Diabetes. 1979;28(12):1039-57.

4. Loghmani E. Diabetes mellitus: type 1 and type 2. Guidelines for adolescent nutrition services. 2005;167-82.

5. Korytkowski M. When oral agents fail: practical barriers to starting insulin. International Journal of Obesity. 2002;26(S3):S18.

6. Choudhury SD, Das SK, Hazra A. Survey of knowledge-attitude-practice concerning insulin use in adult diabetic patients in eastern India. Indian Journal of Pharmacology. 2014;46(4):425.

7. Al-MaskariF, El-Sadig M, Al-Kaabi JM, Afandi B, Nagelkerke N, Yeatts KB. Knowledge, attitude and practices of diabetic patients in the United Arab Emirates. PloS One. 2013;8(1):e52857.

8. Jasper US, Opara MC, Pyiki EB, Akinrolie O. Knowledge of insulin use and its determinants among Nigerian insulin requiring diabetes patients. Journal of Diabetes and Metabolic Disorders. 2014;13(1):10.

9. Dinesh PV, Kulkarni AG, Gangadhar NK. Knowledge and self-care practices regarding diabetes among patients with Type 2 diabetes in Rural Sullia, Karnataka: A community-based, cross-sectional study. Journal of Family Medicine and Primary Care. 2016;5(4):847.

10. Shah VN, Kamdar PK, Shah N. Assessing the knowledge, attitudes and practice of type 2 diabetes among patients of Saurashtra region, Gujarat. International Journal of Diabetes in Developing Countries. 2009;29(3):118.
11. Konduru SS, Ranjan A, Karthik SM, Shaik S, Vakkapatla LS. Assessment of Diabetes Related Knowledge, Attitude and Practice among Diabetics and Non-diabetics using Self Prepared Questionnaire for Awareness of Health Promotion. Indian Journal of Pharmacy Practice. 2017;10(1):33.

12. Wu B, Bell K, Stanford A, et al. Understanding CKD among patients with T2DM: prevalence, temporal trends and treatment patterns-NHANES 2007-2012. BMJ Open Diabetes Research and Care. 2016;4(1):e000154. doi: 10. 1136/ bmjdrc-2015-00015413.

13. Iglesias P, Díez JJ. Insulin therapy in renal disease. Diabetes Obes Metab. 2008;10(10):811-23.

14. DeFronzo RA, Alvestrand A, Smith D, Hendler R, Hendler E, Wahren J. Insulin resistance in uremia. J Clin Invest. 1981;67(2):563-8.

15. Lakhani OJ, Kumar S, Tripathi S, Desai MA, Seth C. Correlation between basal insulin glargine dose required in achieving target fasting blood glucose and various clinical and laboratory parameters in hospitalized noncritical patients. Indian J Endocr Metab. 2018;22(4):469-72.

16. Brod M, Kongsø JH, Lessard S, Christensen TL. Psychological insulin resistance: patient beliefs and implications for diabetes management. Quality of Life Research. 2009;18(1):23.

17. Feba B, Vikas RC, Dhandapani C, Geetha K, Vijayakumar A. Knowledge assessment and patient counseling on diabetic foot care. Indian Journal of Pharmacy Practice. 2012;5(2):11. 